Sección Básica / Basic

Artículo de investigación / Research paper

\title{
Termite (Isoptera) survey in urban area in Northern of Rio de Janeiro State, Brazil
}

\author{
Levantamiento de termitas (Isoptera) en área urbana del norte de Río de Janeiro, Brasil
}

VINÍCIUS GAZAL ${ }^{1}$, OMAR BAILEZ² and ANA MARIA VIANA-BAILEZ ${ }^{3}$

\begin{abstract}
${ }^{1}$ Professor, Dr., Departamento de Entomologia e Fitopatologia, Instituto de Biologia, Universidade Federal Rural do Rio de Janeiro, Rio de Janeiro, Brazil,vgazal@ufrrj.br, https://orcid.org/0000-0002-4227-8639. 2 Professor, Dr., Laboratório de Entomologia e Fitopatologia, Universidade Estadual do Norte Fluminense Darcy Ribeiro, Campos dos Goytacazes, Rio de Janeiro, Brazil, obailez@uenf.br, https://orcid.org/0000-0001-5602-4624. ${ }^{3}$ Professor, Dr., Laboratório de Entomologia e Fitopatologia, Universidade Estadual do Norte Fluminense Darcy Ribeiro, Campos dos Goytacazes, Rio de Janeiro, Brazil, amaria@uenf.br, https://orcid.org/0000-0001-7214-9347.
\end{abstract}

Corresponding author: Vinícius Gazal. Profesor, Dr., Departamento de Entomologia e Fitopatologia, Instituto de Biologia, Universidade Federal Rural do Rio de Janeiro, vgazal@ufrrj.br, https://orcid.org/0000-00024227-8639.

Suggested citation:

GAZAL, V.; BAILEZ, O.; VIANA-BAILEZ, A. M. 2019. Termite (Isoptera) survey in urban area in Northern of Rio de Janeiro State, Brazil. Revista Colombiana de Entomología 45 (1): e7813 https://doi.org/10.25100/socolen. $\mathrm{v} 45 \mathrm{i} 1.7813$

Received: 31-May-2017

Accepted: 20-Aug-2018

Published: 25-Sep-2019

Revista Colombiana de Entomología ISSN (Print): 0120-0488

ISSN (On line): 2665-4385

http://revistacolombianaentomologia.univalle.edu.co/

Open access
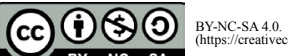

BY-NC-SA 4.0.

Publishers:

Sociedad Colombiana de Entomología

SOCOLEN (Bogotá, D. C., Colombia)

http://www.socolen.org.co

Universidad del Valle (Cali, Colombia)

http://www.univalle.edu.co/

C 2019 Sociedad Colombiana de Entomología - SOCOLEN y Universidad del Valle - Univalle
Abstract: Most pest termites in urban areas in Brazil are exotic species, but native species are becoming an increasing problem. This study aimed to identify termite species infesting trees and houses in urban areas of Campos dos Goytacazes, in the north of Rio de Janeiro State. Trees in the streets of sixteen neighborhoods were inspected for termites. Inspections and interviews were also conducted to verify the occurrence of termites in houses. Termites were recorded in $17 \%$ of the 1,307 trees surveyed. Coptotermes gestroi was the most frequent species (51\% of infested trees), Nasutitermes corniger and Microcerotermes strunckii were present in $38 \%$ and $14 \%$ of infested trees, respectively, and Microcerotermes arboreus was the least common $(1 \%)$. Different termite species coexisted in $14 \%$ of the infested trees (n $=31)$. Termite infestations were recorded in $26 \%$ of the surveyed households $(n=1,020)$. Four species were identified as causing damage: Cryptotermes brevis, C. gestroi, $N$. corniger, and M. strunckii. The most common species was $C$. brevis, affecting 133 residences $(51 \%)$. $C$. gestroi and $N$. corniger were less frequent, but they were responsible for more structural damage than $C$. brevis, which mainly attacked furniture.

Keywords: Urban pest, Neotropical Region, infestation, Kalotermitidae, Rhinotermitidae, Termitidae.

Resumen: La mayoría de las termitas plagas de área urbana en Brasil son especies exóticas, pero algunas especies nativas también están comenzando a representar un problema creciente. Este estudio tuvo como objetivo identificar las especies de termitas que infestan árboles y casas en la ciudad de Campos dos Goytacazes, en el norte del estado de Río de Janeiro. Los árboles de calles de dieciséis vecindarios fueron inspeccionados y los ataques por termitas fueron registrados. También se realizaron entrevistas con propietarios de residencias de los mismos vecindarios y sus domicilios fueron inspeccionados para verificar la ocurrencia de ataque de termitas. Las termitas fueron registradas en $17 \%$ de los 1.307 árboles inspeccionados. La especie más frecuente fue Coptotermes gestroi (51\% de los árboles infestados), Nasutitermes corniger y Microcerotermes strunckii fueron especies de ocurrencia intermedia (38\% y $14 \%$, respectivamente) y Microcerotermes arboreus (1\%) fue la menos común. Las infestaciones de árboles por más de una especie ocurrieron en $14 \%$ de los casos $(n=31)$. Las infestaciones de termitas también se presentaron en $26 \%$ de las residencias inspeccionadas $(\mathrm{n}=1.020)$. Las cuatro especies que causaron daños en domicilios fueron Cryptotermes brevis, C. gestroi, $N$. corniger y $M$. strunckii. La especie más común, encontrada en 133 residencias, fue $C$. brevis $(51 \%)$. C. gestroi y N. corniger pueden ser consideradas especies secundarias en términos de la presencia en las residencias pero fueron responsables por más daños estructurales que $C$. brevis que atacó principalmente el mobiliario.

Palabras clave: Plaga urbana, Región Neotropical, infestación, Kalotermitidae, Rhinotermitidae, Termitidae.

\section{Introduction}

Termites occur in both temperate and tropical areas between $52^{\circ} \mathrm{N}$ and $45^{\circ} \mathrm{S}$ (Lee and Wood 1971; Fontes and Monteiro 1998). These insects include over 3,158 described species distributed in nine families: Mastotermitidae, Archotermopsidae, Hodotermitidae, Stolotermitidae, Kalotermitidae, Stylotermitidae, Rhinotermitidae, Serritermitidae, and Termitidae (Krishna et al. 2013; Constantino 2016). About 534 species have been recorded in Brazil, of four families: Kalotermitidae, Rhinotermitidae, Serritermitidae, and Termitidae (Constantino 2005). However, this statement probably underestimates the real diversity, given that species surveys have not been conducted in many regions of the country (Constantino 1998; 2002; 2019).

The staple food of termites is wood pulp, though the pulp source varies according to the species (Vasconcellos 1999). Most species feed on wood in various stages of 
decomposition, but others feed on humus, lichens, herbivore feces, or fungi grown inside the termite nests (Medeiros 2004; Lima and Costa-Leonardo 2007).

Termites play an important ecological role in natural ecosystems by decomposing organic matter, promoting nutrient cycling, and increasing soil porosity and aeration (Adamson 1943; Lafage and Nutting 1978; Sands and Wood 1978). Changes in soil texture and profile may also help to increase the organic matter content (Lee and Wood 1971; Costa-Leonardo 2002). On the other hand, in urban areas termites can cause significant damage. Increasing urbanization has encroached on areas of agricultural or natural vegetation, resulting in gradual or sudden transformation of termite habitats (Albuquerque et al. 2012). Such changes sometimes may result in the eradication of native termite species, whilst favoring the introduction or dispersal of exotic synanthropic species, which progressively cause greater impact in those new environmental contexts with abundant resources and low number of natural enemies (Milano 1998; Milano and Fontes 2002a; Vasconcellos et al. 2005). Implanted trees play a vital role in the new urban landscape improving the well-being of city inhabitants, and contribute to reductions in air and noise pollution (Milano 1988). However, trees can also provide shelter and food for termites (Fontes 1995; 1998).

The number of termite species considered to be urban pests is relatively small, but they cause enormous damage (Fontes 1995; Amaral 2002). Most termite pests in urban areas in southeastern Brazil are members of the families the Kalotermitidae and Rhinotermitidae (Eleotério and BertiFilho, 2000; Milano and Fontes 2002a), but in other regions of Brazil, arboreal termites from the family Termitidae can also cause significant economic losses (Costa-Leonardo et al. 2007; Albuquerque et al. 2012). Eighteen termite species are considered urban pests in Brazil (Constantino 2005). These termites can attack furniture and the wooden structures of urban buildings, which have usually not undergone preventive treatments (Amaral 2002). The annual economic damages caused by termites in urban areas of the city of São Paulo, Brazil, can reach between US\$ 10 and 20 million (Milano and Fontes 2002a).

Campos dos Goytacazes is a city in southeastern Brazil in a predominantly agricultural region, with large areas dedicated to sugarcane cultivation or livestock. Over the last decade, the city has undergone urban growth as a result of economic changes associated with the expansion of activities related to oil exploration. In this study, there were identified the termitofauna associated with trees and residential buildings of the city.

\section{Materials and methods}

Termites were sampled in the urban area of the city of Campos dos Goytacazes, Rio de Janeiro, Brazil (21 ${ }^{\circ} 45^{\prime} 16^{\prime \prime} \mathrm{S}$, $\left.41^{\circ} 19^{\prime} 28^{\prime \prime} \mathrm{W}\right)$. The city has an area of $4,826 \mathrm{~km}^{2}$ and a population of about 480,000 inhabitants. The climate is hot and humid and the average temperature is $25.2^{\circ} \mathrm{C}$ (Mendonça et al. 2007).

The survey was carried out in 16 of the city's 30 neighborhoods. The neigborhoods were randomly chosen in the map of the Municipal Planning of Campos dos Goytacazes: Parque Fazendinha, Parque Rosário, Turfe, Parque Tamandaré, Parque Avenida Pelinca, Parque São Benedito, Parque Flamboyant II, Parque Tarcísio Miranda,
IPS, Parque São Pedro, Centro, and Parque Riachuelo.

Eight streets in each neighborhood were randomly selected. A $200 \mathrm{~m}$ section with at least 20 trees along the sidewalk was sampled for each street. The trees were inspected to determine if termites were attacking or nesting in them. In addition, twelve houses on the selected area were inspected: the external area (trees, fences, walls, and other structures that could serve as shelter to termites) and the internal area (furniture, wood from the roof, doors, windows and frames) were examined for signs of termite infestation. The specimens collected were stored in $80 \%$ alcohol and identified with the aid of identification keys and reviews (Fontes 1982; 1985; Constantino 1998; 1999; 2002; Ferraz 2000). Samples were deposited in the Entomological Collection of the Entomology and Phytopathology Department of the Federal Rural University of Rio de Janeiro (UFRRJ).

The proportions of trees and buildings infested with different termite species were compared using $\chi^{2}$ tests. Differences were considered significant when the probability level was higher than $5 \%$ divided by the total number of comparisons made (e.g. if five species were compared, the results were considered significant when the probability was $<5 \% / 4$, i.e. $<1.25 \%$ ) (McDonald 2008).

\section{Results}

Termites were found in $67 \%(\mathrm{n}=91)$ of the sampled streets $(\mathrm{n}$ $=136)$ and $17 \%(n=228)$ of the surveyed trees $(n=1,307)$.

Four species of termites were identified in the trees: Coptotermes gestroi (Wasmann, 1896) (Rhinotermitidae), Nasutitermes corniger (Motschulsky, 1855) (Termitidae), Microcerotermes strunckii (Sörensen, 1884) (Termitidae), and Microcerotermes arboreus (Emerson, 1925) (Termitidae). The most common species was $C$. gestroi $\left(\chi^{2}=29.54\right.$; degrees of freedom $[\mathrm{df}]=3, \mathrm{P}<0.001)$ recorded in $51 \%$ of the infested trees, while $M$. arboreus was the least common ( $1 \%$ of the infested trees) (Fig. 1).

Different species of termites coexisted in the same tree in $14 \%$ of the samplings $(n=31)$. Coexistence in a same tree involved two species in $97 \%$ of cases and three species in $3 \%$. C. gestroi was present in all cases of coexistence. The most common association was $C$. gestroi-N. corniger $(52 \%)$, followed by $C$. gestroi-M. strunckii $(45 \%)$ and finally by $C$. gestroi-M. strunckii-M. arboreus $(3 \%)\left(\chi^{2}=46,08 ; \mathrm{df}=2, \mathrm{P}\right.$ $<0.001)$.

Termites infested $26 \%$ of the 1,020 the homes inspected. Four species were found: C. brevis (Walker, 1853) (Kalotermitidae), C. gestroi, N. corniger and M. strunckii. $C$. brevis was the most common species, sampled in 51 $\%$ of the residences $(\mathrm{n}=133)$. C. gestroi, $N$. corniger and M. strunckii were sampled in $30 \%, 21 \%$ and $1 \%$ of the dwellings, respectively $\left(\chi^{2}=8.30 ; \mathrm{df}=3, \mathrm{P}<0.01\right.$, Fig. 2$)$.

Seven houses were infested with more than one species of termite: C. brevis-C. gestroi $(\mathrm{n}=2), C$. brevis $-N$. corniger $(\mathrm{n}=2), C$. gestroi-N. corniger $(\mathrm{n}=2)$ and $C$. brevis-C. gestroi-N. corniger $(\mathrm{n}=1)\left(\chi^{2}=5.81, \mathrm{df}=3\right.$, n.s. $)$.

\section{Discussion}

This study identified species of four genera of termites infesting trees and homes in the urban area of Campos dos Goytacazes, Rio de Janeiro. The subterranean termite $C$. gestroi and the arboreal termite $N$. corniger were the most 


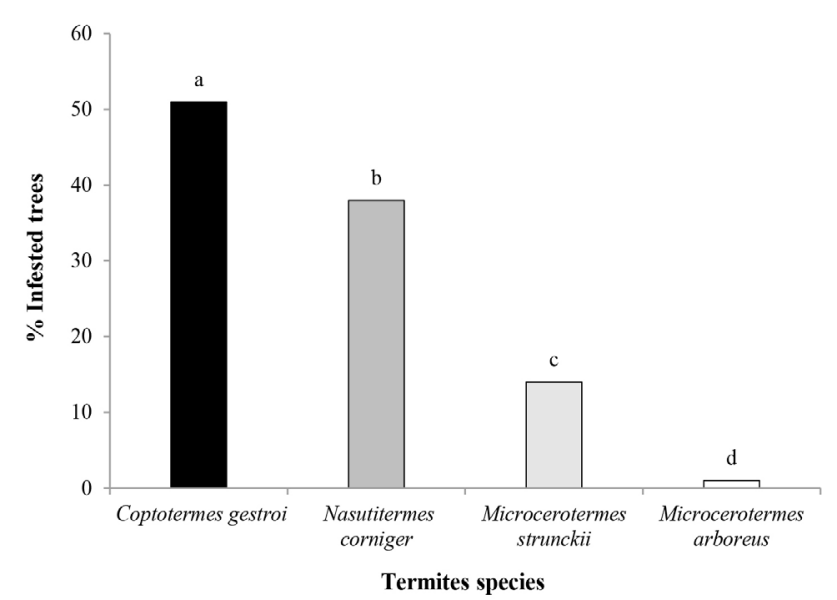

Figure 1. Percentage of infested trees $(\mathrm{n}=228)$ by Coptotermes gestroi, Nasutitermes corniger, Microcerotermes strunckii and Microcerotermes arboreus in the streets of Campos dos Goytacazes, RJ ( $\chi^{2}$ test, different letters indicate significant difference $\mathrm{P}<0.05 / 4)$.

frequent species infesting trees, while the dry-wood termite C. brevis was the most common species attacking furniture in homes and M. strunckii was rarely found causing infestation. The occurrence of the Asian termite C. gestroi on trees and residences in urban areas of Campos dos Goytacazes is the first record in the Northern Rio de Janeiro State. This fact corroborates the high dispersal ability and good adaptability of this species, which was introduced in the coastal cities of Rio de Janeiro and Santos in the early twentieth century (Araujo 1970) and dispersed to other inland districts in the southeastern region such Campinas, Rio Claro, Ribeirao Preto (Martins et al. 2010). The frequent occurrence of C. gestroi is likely to be related to its capacity to develop in warm, lowlying areas with high rainfall and human habitation ( $\mathrm{Li}$ et al. 2013). These characteristics match those observed in Campos dos Goytacazes (Mendonça et al. 2007).

The spread of urban areas seems to have favored increases in the densities of some native termite species. The destruction and replacement of natural vegetation, which provides termites with food and shelter, triggers an ecological imbalance in the ecosystem around cities (Cancello et al. 1998; Milano 1998). At the same time, the presence of native and other trees in new urban areas favored the proliferation or the nesting of these termites in the urban environment. The trees provide food and nesting sites, while building materials containing cellulose represent an increase in the supply of food (Bustamante and Martius 1998; Vasconcellos and Bandeira 2000; Vasconcellos et al. 2002).

The native arboreal termite $N$. corniger was the second most frequent species found in trees and residences in Campos dos Goytacazes. Decades ago, this species was mainly observed in natural or agricultural environments (Fontes and Milano 2002). However, the incidence of $N$. corniger in urban households has risen in recent years (Costa et al. 2009; Albuquerque et al. 2012; Mello et al. 2014) what indicates its increasing importance as an urban pest. A major reduction in the natural vegetation in urban-transition areas could be the main cause for increases in $N$. corniger populations in Recife city, capital of Pernambuco State in Brazilian northeastern region (Milano and Fontes 2002b; Albuquerque et al. 2012). This termite was assigned as being more abundant in disturbed areas as in secondary forests (Bandeira et al. 2003; Vasconcellos et al. 2005), and the

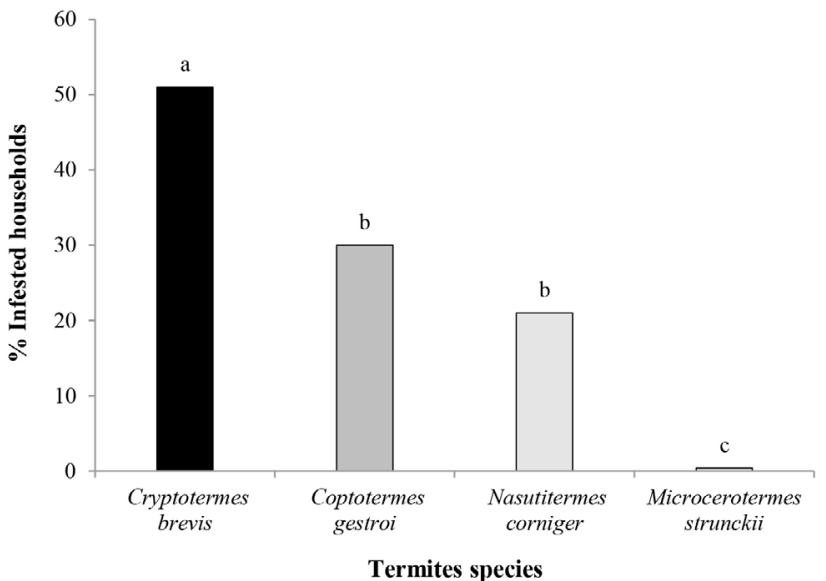

Figure 2. Percentage of infested residences $(\mathrm{n}=261)$ by Cryptotermes brevis, Coptotermes gestroi, Nasutitermes corniger and Microcerotermes strunckii in districts of Campos dos Goytacazes City, RJ ( $\chi^{2}$ test, different letters indicate significant difference $\mathrm{P}<0.05 / 4$ ).

construction of polycalic and/or polygynic nests significantly increases the foraging area and reproductive capacity of each colony, allowing the termite to spread and colonize new habitats (Thorne 1982; Vasconcellos and Bandeira 2006), which may include urban areas.

The arboreal species of Microcerotermes are abundant in natural areas of Brazil, and some have been reported attacking urban buildings in the Amazon, the Northeast region, and the coast of São Paulo in the southeast (Bandeira et al. 1998; Vasconcellos and Bandeira 2000; Costa- Leonardo et al. 2007). In the natural habitat, these termites build nests on living trees from which they feed, and can also forage in nearby trees (Mill 1982; Torales 1998; Costa-Leonardo et al. 2007). In the urban area of Campos dos Goytacazes, $M$. strunckii was the third most common species found in trees. Previous studies reported that Microcerotermes species were opportunistic pests in transition areas adjacent to urban areas (Bandeira 1998; Bandeira et al. 1998; Vasconcellos et al. 2002) what suggests that they may be increasing in importance as urban pests, like $N$. corniger.

The coexistence of different species of termites in the same tree is a challenge in terms of territoriality and obtaining of food resources. However, coexistences may occur among species of termites exhibiting different behaviors in terms of their preferred part of the tree for nesting and food preferences. Jones and Trosset (1991) reported that competition for nesting sites was more common than competition for food between sympatric species. However, when these resources are scarce, they will compete for food (Thorne and Haverty 1991).

This may be the main reason preventing coexistence between arboreal species such as M. strunckii and $N$. corniger, which nest and forage in the same part of the tree. The termite C. gestroi was present in all the cases of coexistence reported in this study. This is probably due to the fact that this species nests inside the trunk or deep root area in the soil (Fontes 1998; Costa-Leonardo 2002; Milano and Fontes 2002a).

The dry-wood termite $C$. brevis was the main species causing residential infestations, often unnoticed by the homeowners because of the unobtrusive nature of their activity. This termite can be detected by its winged display, and the accumulation of fecal pellets. However, the colonies 
develop slowly and may take many years to release winged individuals, while fecal pellets may not be obvious depending on the size of the colony (Ferreira 2008). Consequently, infestations may not appear until the damage is extensive (Bandeira et al. 1998; Eleotério and Berti-Filho 2000). This difficulty in detecting $C$. brevis infestations undoubtedly contributes to its spread and abundance in homes compared with other species of termites (Fontes 1995; Milano and Fontes 2002b). This termite mainly attacks furniture while attacks on structural timbers are largely caused by other species (Costa-Leonardo 2002).

$C$. gestroi and $N$. corniger may be considered as secondary species in terms of their occurrence in residential buildings, but they can be responsible for more structural damage than C. brevis (Milano and Fontes 2002b). This is probably the result of a preference for the types of wood used in structural timbers (Gazal et al. 2010; 2012) or by the size of the colonies, since dry-wood termite colonies are small, with hundreds to a few thousand individuals (Nutting 1970; Ferreira 2008), while mature colonies of $C$. gestroi can exceed one million individuals (Costa-Leonardo et al. 2007). Similarly, $N$. corniger colonies can reach over 400,000 individuals (Thorne 1982; Martius 1994; Vasconcellos et al. 2008).

\section{Acknowledgements}

We thank Gilson Silva Filho and Arli de Fátima for technical support in the laboratory. This research was supported by the Coordenação de Aperfeiçoamento de Pessoal de Nível Superior (CAPES) and CNPq, Brazil.

\section{Literature cited}

ADAMSON, A. M. 1943. Termites and the fertility of soils. Tropical Agriculture 20: 107-202.

AlBUQUERQUE, A. C.; MATIAS, G. R. S.; COUTO, A. A. V. O.; OLIVEIRA, M. A. P.; VASCONCELLOS, A. 2012. Urban termites of Recife, Northeast Brazil (Isoptera). Sociobiology 59: 1-6. https://doi.org/10.13102/sociobiology.v59i1.675

AMARAL, R. D. A. M. 2002. Diagnóstico da ocorrência de cupins xilófagos em árvores urbanas do bairro de Higienópolis, na cidade de São Paulo. Dissertation, ESALQ, Universidade de São Paulo, Brasil. 71 p.

ARAUJO, R. L. 1970. Termites of the Neotropical Region. pp. 527576. In: Krishna, K.; Weesner, F. M. (Eds.). Biology of termites. Volume. II. Academic Press. New York. 643 p.

BANDEIRA, A. G. 1998. Danos causados por cupins na Amazônia brasileira. pp. 87-98. In: Fontes, L. R.; Berti Filho, E. (Eds.). Cupins: O desafio do conhecimento. Fundação de Estudos Agrários Luiz de Queiroz. Piracicaba. Brazil. 512 p.

BANDEIRA, A. G.; MIRANDA, C. S.; VASCONCELlOS, A. 1998. Danos causados por cupins em João Pessoa, Paraíba, Brasil. pp. 75-85. In: Fontes, L. R.; Berti Filho, E. (Eds.). Cupins: O desafio do conhecimento. Fundação de Estudos Agrários Luiz de Queiroz. Piracicaba. Brazil. 512 p.

BANDEIRA, A. G.; VASCONCELLOS, A.; SILVA, M. P.; CONSTANTINO, R. 2003. Effects of habitat disturbance on the termite fauna in a highland humid forest in the Caatinga domain, Brazil. Sociobiology 42: 117-127.

BUSTAMANTE, N. C. R., MARTIUS, C. 1998. Nutritional preferences of wood-feeding termites inhabiting floodplain forest of the Amazon River, Brazil. Acta Amazonica 28: 301307. https://doi.org/10.1590/1809-43921998283307

CANCELLO, E. M.; ZORZENON, F. J.; POTENZA, M. R.; CAMPOS, T. B. 1998. Bioecologia e sistemática. pp. 8-20. In: Zorzenon, F. J.; Potenza, M. R. (Eds.). Cupins: pragas em áreas urbanas. Boletim Técnico Volume. X. Instituto Biológico. São Paulo. Brazil. 10 p.

CONSTANTINO, R. 1998. Catalog of the living termites of the New World (Insecta: Isoptera). Arquivos de Zoologia 35: 135231. https://doi.org/10.11606/issn.2176-7793.v35i2p135-230

CONSTANTINO, R. 1999. Chave ilustrada para identificação dos gêneros de cupins (Insecta: Isoptera) que ocorrem no Brasil. Papéis Avulsos de Zoologia 40: 387-448.

CONSTANTINO, R. 2002. The pest termites of South America: taxonomy, distribution and status. Journal of Applied Entomology 126: 355-365. https://doi.org/10.1046/ j.1439-0418.2002.00670.x

CONSTANTINO, R. 2005. Padrões de diversidade e endemismo de térmitas no bioma Cerrado. pp. 319-333. In: Scariot, A. O.; Silva, J. C. S. Felfili, J. M. (Eds.). Cerrado: Ecologia, biodiversidade e conservação. Ministério do Meio Ambiente. Brasília. Brazil. 439 p.

CONSTANTINO, R. 2016. Termite database. Brasília, University of Brasília. [Updated Jan 2018]. Available at: http://termitologia. unb.br. [Review data: 10 March 2019].

CONSTANTINO, R. 2019. Isoptera. Catálogo Taxonômico da Fauna do Brasil. Universidad de Brasilia (UnB). Available in: http://fauna.jbrj.gov.br/fauna/faunadobrasil/188494. [Review data: 15 April 2019].

COSTA, D. A.; FILHO, K. E. S.; BRANDÃO, D. 2009. Padrão de distribuição de cupins na região urbana de Goiânia. Iheringia, Série Zoologia 99: 364-367. https://doi.org/10.1590/S007347212009000400004

COSTA-LEONARDO, A. M. 2002. Cupins-Praga: morfologia, biologia e controle. Divisa, Rio Claro. $128 \mathrm{p}$.

COSTA-LEONARDO, A. M.; CASARIN, F. E.; CAMARGODIETRICH, C. R. R. 2007. Identificação e práticas de manejo de cupins em áreas urbanas. pp. 41-54. In: Pinto, A. S.; Rossi, M. M.; Salmeron E. (Eds.). Manejo de pragas urbanas. CP 2. Piracicaba. Brazil. 208 p.

ELEOTÉRIO, E. S. R.; BERTI FILHO, E. 2000. Levantamento e identificação de cupins (Insecta: Isoptera) em área urbana de Piracicaba-SP. Ciência Florestal 10: 125-139. https://doi. org/10.5902/19805098400

FERRAZ, M. V. 2000. Estudo taxonômico e aspectos da biologia de Coptotermes Wasmann, 1896 (Isoptera, Rhinotermitinae) nas Américas. Thesis, Universidade de São Paulo. Brazil. 213 p.

FERREIRA, M. T. 2008. Dispersal flight, post flight behavior and early colony development of the West Indian drywood termite Cryptotermes brevis (Walker) (Isoptera: Kalotermitidae). Ph. D. dissertation University of Florida. U.S.A. 54 p.

FONTES, L. R. 1982. Novos táxons e novas combinações nos cupins nasutos geófagos da região Neotropical (Isoptera, Termitidae, Nasutitermitinae). Revista Brasileira de Entomologia 26: 99-108.

FONTES, L. R. 1985. New genera and new species of Nasutitermitinae from the Neotropical region (Isoptera, Termitidae). Revista Brasileira de Zoologia 3: 7-25. https://doi.org/10.1590/ S0101-81751985000100002

FONTES, L. R. 1995. Cupins em áreas urbanas. pp. 57-76. In: Berti Filho, E.; Fontes, L. R. (Eds.). Alguns aspectos atuais da biologia e controle de cupins. Fundação de Estudos Agrários Luiz de Queiroz. Piracicaba. Brazil. 183 p.

FONTES, L. R. 1998. Considerações sobre a complexidade da interação entre o cupim subterrâneo Coptotermes havilandi, e a arborização no ambiente urbano. pp. 109-124. In: Fontes, L. R.; Berti Filho, E. (Eds.). Cupins: O desafio do conhecimento. Fundação de Estudos Agrários Luiz de Queiroz. Piracicaba. Brazil. 512 p.

FONTES, L. R.; MONTEIRO, A. R. 1998. Etimologia e pronúncia dos nomes científicos dos cupins. pp. 19-43. In: Fontes, L. R.; Berti Filho, E. (Eds.). Cupins: O desafio do conhecimento. Fundação de Estudos Agrários Luiz de Queiroz. Piracicaba. Brazil. 512 p.

FONTES, L. R.; MILANO, S. 2002. Termites as urban problem in South America. Sociobiology 40: 107-147. 
GAZAL, V.; BAILEZ, O.; VIANA-BAILEZ, A. M. 2010. Wood preference of Nasutitermes corniger (Isoptera: Termitidae). Sociobiology 55: 433-443.

GAZAL, V.; BAILEZ, O.; VIANA-BAILEZ, A. M.; AGUIARMENEZES, E. L.; MENEZES, E. B. 2012. Decayed wood affecting the attraction of the pest arboretum termite Nasutitermes corniger (Isoptera: Termitidae) to resoursce foods. Sociobiology 59: 287-295. https://doi.org/10.13102/ sociobiology.v59i1.684

JONES, S. C.; TROSSET, M. W. 1991. Interference competition in desert subterranean termites. Entomologia Experimentalis et Applicata; 69: 83-90. https://doi.org/10.1111/j.1570-7458.1991. tb02398.x

KRISHNA, K.; GRIMALDI, D. A.; KRISHNA, V.; ENGEL, M. S. 2013. Treatise on the Isoptera of the world: 1. Introduction. Bulletin of the American Museum of Natural History 377: 1-200. https://doi.org/10.1206/377.1

LAFAGE, J. P.; NUTTING, W. L. 1978. Nutrient dynamics of termites. pp. 309-319. In: Brian, M. V. (Ed.). Production ecology of ants and termites. Cambridge University Press. Cambridge. $428 \mathrm{p}$.

LEE, K. E.; WOOD, T. G. 1971. Termites and soils. Academic Press, London. $251 \mathrm{p}$.

LI, H. F.; FUJISAKI, I.; SU, N. Y. 2013. Predicting habitat suitability of Coptotermes gestroi (Isoptera: Rhinotermitidae) with species distribution models. Journal of Economic Entomology 106: 311321. https://doi.org/10.1603/EC12309

LIMA, J. T.; COSTA-LEONARDO, A. M. 2007. Recursos alimentares explorados pelos cupins (Insecta: Isoptera). Biota Neotropica 7: 243-250. https://doi.org/10.1590/S167606032007000200027

MARTINS, C.; FONTES, L. R.; BUENO, O. C.; MARTINS, V. G. 2010. Coptotermes gestroi (Isoptera: Rhinotermitidae) in Brazil: possible origins inferred by mitochondrial cytochrome oxidase II gene sequences. Genome 53: 651-657. https://doi.org/10.1139/ G10-044

MARTIUS, C. 1994. Termite nests as structural elements of the Amazon floodplain forest. Andrias 13: 137-150.

MCDONALD, J. H. 2008. Handbook of biological statistics. Sparky House Publishing, Maryland, U.S.A. 287 p.

MEDEIROS, M. B. 2004. Metabolismo da celulose em Isoptera. Revista Biotecnologia Ciência e Desenvolvimento 33: 76-81.

MELlO, A. P.; COSTA, B. G.; SILVA, A. C.; SILVA, A. M. B.; BEZERRA-GUSMÃO, M. A. 2014. Termite infestation in historical buildings and residences in the semiarid region of Brazil. Sociobiology 61: 318-323. https://doi.org/10.13102/ sociobiology.v61i3.318-323

MENDONÇA, J. C.; SOUSA, E. F.; BERNARDO, S.; SUGAWARA, M. T.; PEÇANHA, A. L.; GOTTARDO, R. D. 2007. Determinação do coeficiente cultural (kc) do feijoeiro (Phaseolus vulgaris L.), em Campos dos Goytacazes, RJ. Revista Brasileira de Engenharia Agrícola e Ambiental 11: 471-475. https://doi.org/10.1590/S141543662007000500004

MILANO, M. S. 1988. Avaliação quali-quantitativa e manejo da arborização urbana: exemplo de Maringá-PR. Thesis, Universidade Federal do Paraná. Curitiba, Brazil. 120 p.

MILANO, S. 1998. Diagnóstico e controle de cupins em área urbana. pp. 45-74. In: Fontes, L. R.; Berti Filho, E. (Eds.). Cupins: O desafio do conhecimento. Fundação de Estudos Agrários Luiz de Queiroz. Piracicaba. Brazil. 512 p.

MILANO, S.; FONTES, L. R. 2002a. Cupim e cidade: Implicações ecológicas e controle. São Paulo, Brazil. 142 p.

MILANO, S.; FONTES, L. R. 2002b. Termite pests and their control in urban Brazil. Sociobiology 40 (1): 63-177.
MILL, A. E. 1982. Faunal studies on termites (Isoptera) and observations on their predators (Hymenoptera: Formicidae) in the Amazon basin. Revista Brasileira de Entomologia 26: 253-260.

NUTTING, W. L. 1970. Composition and size of some termite colonies in Arizona and Mexico. Annals of the Entomological Society of America 63: 1105-1110. https://doi.org/10.1093/ aesa/63.4.1105

SANDS, W. A.; WOOD, T. G. 1978. The role of termites in ecosystems. pp. 245-292. In: Brian, M. V. (Ed.). Production ecology of ants and termites. Cambridge University Press. Cambridge. 428 p.

THORNE, B. L. 1982. Polygyny in termites: multiple primary queens in colonies of Nasutitermes corniger (Motschulsky) (Isoptera: Termitidae). Insectes Sociaux 29: 102-117. https://doi. org/10.1007/BF02224531

THORNE, B. L.; HAVERTY, M. I. 1991. Review of intracolony, intraspecific, and interspecific agonism in termites. Sociobiology 19: $115-145$.

TORALES, G. J. 1998. Rol dos isópteros en la Argentina. pp. 219225. In: Fontes, L. R.; Berti Filho, E. (Eds.). Cupins: O desafio do conhecimento. Fundação de Estudos Agrários Luiz de Queiroz. Piracicaba. Brazil. 512 p.

VASCONCELLOS, A. 1999. Estrutura e dinâmica de ninhos policálicos de uma espécie de Nasutitermes (Isoptera: Termitidae) em Mata Atlântica e no meio urbano de João Pessoa, Paraíba, Brasil. $\mathrm{PhD}$ dissertation, Universidade Federal da Paraíba. João Pessoa, Brazil. 84 p.

VASCONCELlOS, A.; BANDEIRA, A. G. 2000. Avaliação do consumo de madeira por espécies de Nasutitermes e Microcerotermes (Insecta, Isoptera, Termitidae). Revista Nordestina de Biologia 14: 17-24.

VASCONCELLOS, A.; BANDEIRA, A. G. 2006. Populational and reproductive status of a polycalic colony of Nasutitermes corniger (Isoptera, Termitidae) in the urban area of João Pessoa, NE Brazil. Sociobiology 47: 165-174.

VASCONCELLOS, A.; BANDEIRA, A. G.; MIRANDA, C. S.; SILVA, M. P. 2002. Termites (Isoptera) pests in buildings in João Pessoa. Brazil. Sociobiology 40: 1-6.

VASCONCELlOS, A.; MELO, A. C. S.; SEGUNDO, E. M. V.; BANDEIRA, A. G. 2005. Cupins de duas florestas de restinga do Nordeste Brasileiro. Iheringia, Série Zoologia 95: 127-131. https://doi.org/10.1590/S0073-47212005000200003

VASCONCELLOS, A.; BANDEIRA, A. G.; ALMEIDA, W. O.; MOURA, F. M. S. 2008. Térmitas construtores de ninhos conspícuos em duas áreas de Mata Atlântica com diferentes níveis de perturbação antrópica. Neotropical Entomology 37: 15-19. https://doi.org/10.1590/S1519-566X2008000100003

\section{Origin and funding}

This paper has been based on a chapter of the Ph. D. thesis from Universidade Estadual do Noroeste Fluminense, Brazil, entitled "Comportamento de forrageamento de Nasutitermes corniger (Motschulsky) (Isoptera: Termitidae) e sua ocorrência em áreas urbanas", authored by Vinicius Gazal. The research was supported by the Coordenação de Aperfeiçoamento de Pessoal de Nivel Superior (CAPES) and by the Conselho Nacional de Desenvolvimento Cientifico e Tecnológico (CNPq), Brazil.

\section{Author's contribution}

Vinicius Gazal: Designed the experiment, carried out insect sampling, performed termite's species identification and the data analysis, prepared the figures and write the manuscript.

Omar Bailez: Designed the experiment, carried out insect sampling, performed the data analysis and write and reviewed the manuscript.

Ana Maria Viana-Bailez: Designed the experiment and reviewed the manuscript. 